"How South African open distance learning students use social media: a survey"

\begin{tabular}{|c|c|c|}
\hline AUTHORS & Letitia E. Fourie & \\
\hline ARTICLE INFO & $\begin{array}{l}\text { Letitia E. Fourie (2016). How So } \\
\text { social media: a survey. Problem } \\
\text { doi:10.21511/ppm.14(1).2016.0 }\end{array}$ & $\begin{array}{l}\text { istance learning students use } \\
\text { s in Management, 14(1), 71-78. }\end{array}$ \\
\hline DOI & http://dx.doi.org/10.21511/ppm.1 & \\
\hline RELEASED ON & Wednesday, 02 March 2016 & \\
\hline JOURNAL & "Problems and Perspectives in I & \\
\hline FOUNDER & LLC "Consulting Publishing Cor & "erspectives" \\
\hline & & $\begin{array}{l}\text { ニ- } \\
\text { =- }\end{array}$ \\
\hline NUMBER OF REFERENCES & NUMBER OF FIGURES & NUMBER OF TABLES \\
\hline 0 & 0 & 0 \\
\hline
\end{tabular}

(C) The author(s) 2022. This publication is an open access article. 
Letitia E. Fourie (South Africa)

\title{
How South African open distance learning students use social media: a survey
}

\begin{abstract}
Various studies have been conducted on the use of social media but there is a gap in the literature with regard to social media use in South Africa as well as the difference in social media usage between Generation Y and older students. Thus the main purpose of this article is to determine how open distance learning (ODL) students use social media and if age makes a difference in social media usage. An online self-administered questionnaire was sent to a sample of first year ODL students via email that consisted of a Likert scale that surveyed how they used social media. The results indicate that students mostly use social media for entertainment purposes. A slight difference in the use of social media by Generation Y students and older students are found. Generation Y use social media mainly for entertainment purposes whereas older students indicate that they use it more for information seeking purposes. By taking these results into consideration, organizations can develop more tailored marketing messages to the consumers in the different age groups. If they want to reach Generation $Y$ with a marketing message it should be more entertaining. Whereas marketing message aimed at older students should be in the form of more informative messages.
\end{abstract}

Keywords: social media, social media usage, marketing, open distance learning, Generation Y, age, South Africa. JEL Classification: M001.

\section{Introduction}

The marketing playing field has drastically changed in the last decade. The traditional marketing communications mix used by universities on a daily basis to market products and services were stirred up with the introduction of Web 2.0 (Thackeray et al., 2008; du Plessis, Bothma, Jordaan and van Heerden, 2005). This emergence of Web 2.0 has provided marketers with new social media marketing platforms which can also be used to reach the intended target market (Makrez, 2015). Social media marketing is mainly done by encouraging people to share their experiences of products, services and companies with their peers by means of user-generated content. This means that there is an opportunity for direct communicate with customers via social networks, micro blogging, blogs and video sharing, which is in a form that customers understand and welcome (Mangold and Faulds, 2009; Thackeray et al., 2008; Scott, 2007). The target market can now be engaged with directly by providing them with information that is useful, and in the process built a long term relationship based on trust and loyalty. This usergenerated content on social media sites has become invaluable to millions of users (Agichtein, Castillo, Donato, Gionis and Mishne, 2008) as they seek authenticity and want to participate in the conversation, instead of just being on the receiving end of one-way communication (Scott, 2007). How the target market uses social media is of great importance. It can provide great insight into the target market's lives. This insight acquired can in turn lead organizations producing a marketing strategy that is more tailored to their intended target market.

(C) Letitia Fourie, 2015

Letitia Fourie, M.Com. Business Management, Lecturer, Department of Marketing and Retail Management, University of South Africa, South Africa.
Previous research conducted found that social media activities deal mostly with socialization, entertainment and the contribution and retrieval of information (Whiting and Williams, 2013; Constantinides and Stagno, 2011; Heinonen, 2011; De Valck, 2009). In South Africa a study by Dlodlo and Dhurup (2013) found that social media were mainly described as being used for enjoyment, usefulness, ease of use and critical mass. In another study conducted on the usage of social media in a higher education environment it was found that students mainly use social media for interacting socially looking for information and that contribution of content is limited to photo and video sharing (Constantinides and Stagno, 2011). As the social media usage of open distance learning (ODL) students was not yet researched, this article made use of the same Likert scale as the article by Constantinides and Stagno (2011) to measure social media usage among ODL students.

This article focusses on the use of social media by ODL students. The article will also deliberate on whether different age groups use social media for different reasons. By identifying how ODL students use social media, ODL universities can tailor their marketing efforts to students more effectively. The next section of this article will focus on the existing literature with regard to social media usage and how different age groups use social media.

\section{Literature review}

Social media is a term that has been used a great deal over the past number of years. It can be described as online communities that share with one another by having conversations (Safko and Brake, 2009). These "conversations" involve sharing user-generated content including facts, opinions, experiences, personal beliefs and rumours using words, pictures, 
video and audio amongst participants (Xiang and Gretzel, 2010; Safko and Brake, 2009). This means that consumers anywhere in the world can now build relationships with one another because of social media (Bolotaeva and Cata, 2011).

The social media phenomenon has its roots in the first social network called Sixdegrees.com. It was launched by Andrew Weinrech as a result of the theory of "six degrees of separation" which claims that everyone in the world can be connected through a chain of connections that has no more than five intermediaries. Due to funding restraints it was closed down in 2000 (Barker et al., 2013). Not long after sixdegrees.com was closed down, Mark Zuckerberg started Facebook in 2004 as a social medium for students to get acquainted at Harvard. More than half of the student body registered with Facebook in less than a month. Dustin Moskovitz, Eduardo Saverin and Chris Hughes joined Zuckerberg to help promote the site. In the first quarter of 2015, Facebook reported 1.44 billion monthly active users, with roughly 9.4 million of these users being South Africans in 2014 (Facebook, 2015; World Wide Worx, 2014; Safko and Brake, 2009). In May 2012 Facebook was listed on the New York Stock Exchange. In 2015 thus far Facebook is the most popular social network and is the third most visited website in South Africa (Alexa, 2015).

Social media are much more than just Facebook. Today, it consists of various categories that are used to facilitate the dialogue between people. There is a comprehensive list of hundreds of social media platforms available. Current examples of social media include social networking sites like Facebook and LinkedIn, micro blogging sites like Twitter, video sharing sites like YouTube, social curation on Pinterest and blogs.

In 2014 Twitter reported about 500 million users with 288 million of these users being active, while YouTube had in excess of 4 billion views per day. LinkedIn grew immensely popular with 332 million users in 2014 and Pinterest recorded 70 million users in 2015. There are approximately 184 million bloggers and more or less 346 million people that read these blogs (Anon, 2015; Facebook, 2015; Zarrella, 2009).

Research conducted in the USA on social media use indicated a steady increase in the use of social media by all internet users between the ages of 18-65+ years since 2005 to 2014. Of all internet users the majority of users are between the ages of 18-49 years (Pew Research Centre A, 2015). The most popular social media site is Facebook and is access at least once a day (Pew Research Centre B, 2015).
The picture in South Africa looks similar with 11.8 million (22\%) active social media accounts. The top active social media platforms are Whatsapp and Facebook. It is unclear what South African users use social media specifically for. The report do indicate that they engage in the following activities online: watching videos, playing games, using location based search, mobile banking, share web pages, research products and buy products online (Shezi, 2015).

\section{Social media use}

A study conducted in 2014 by Statista (2014) indicated that social media are used globally for following a favorite brand, discovering new brands, for research a brand including other's feedback, providing comments about experience with a brand (positive/negative) viewed videos, liked and shared products. Overall more consumers between the ages of 18-24 engaged in these activities than consumers older than 30 years. De Valck (2009) identified six users based on their frequency of use, time spent on social media, supply of information, retrieval of information and participation in discussions. The six users can be seen in the table below.

Table 1. Social media user types

\begin{tabular}{|c|c|}
\hline User & Communication or participation \\
\hline Core members & $\begin{array}{l}\text { Most frequent and longest visits } \\
\text { Most active participants } \\
\text { Retrieve and supply information } \\
\text { Participate actively in discussions }\end{array}$ \\
\hline Conversationalists & $\begin{array}{l}\text { Frequent but short visits } \\
\text { Supplying and discussing information } \\
\text { Retrieve and supply information but not as much } \\
\text { as core members }\end{array}$ \\
\hline Informationalists & $\begin{array}{l}\text { Less frequent visitors but spend longer time } \\
\text { Retrieve information and supply information } \\
\text { Do not really participate in discussions }\end{array}$ \\
\hline Hobbyists & $\begin{array}{l}\text { Visit frequently for extended time } \\
\text { Low retrieval and supply of information } \\
\text { Low participation in discussions }\end{array}$ \\
\hline Functionalists & $\begin{array}{ll} & \text { Largest group } \\
& \text { Retrieve information but do not supply information } \\
& \text { Visit less frequently }\end{array}$ \\
\hline Opportunists & $\begin{array}{l}\text { Least frequent visitors and visits are short } \\
\text { Mainly retrieve information } \\
\text { Hardly supply information or join discussions }\end{array}$ \\
\hline
\end{tabular}

Heinonen (2011) grouped activities on social media into three categories depending on the motivation for the activity, namely information processing, entertainment activities and social connection. Constantinides and Stagno (2011) categorized social media activities into social engagement, information seeking and content contribution. As can be seen from the previous research conducted above, social media activities revolve among entertainment, socialization, information contribution and information retrieval. We will now consider these categories in more detail: 


\section{Entertainment}

Due to the nature of the content available on social media sites, the entertainment value is evident. Watching of videos, reading of interesting links shared, viewing pictures and playing games are some of the activities that can be grouped under entertainment. Another entertaining activity is that of socialization.

\section{Socialization}

Humans are social beings in nature and cannot function alone. It is natural to want to communicate and share with people around you. With social media it is easy to find people with similar interests on social media and to receive recognition from others with a like or retweet, which can result in a person's ego being lifted (Chalesworth, 2015). The sharing of links, photographs and videos with friends or followers are easy on social media and can be done with the click of a button. There is a multitude of content that can be viewed on social media that are shared by others. Users are able to stay in touch with contacts and also find new contacts. They can even make appointments or join events.

\section{Information retrieval}

Social media speak to the inherent human behavior of wanting to seek out information and self-educate (Whiting and Williams, 2013). Social media provide people with a plethora of information from peers which they trust more than marketing messages (Chalesworth, 2015). Reviews that are written by other users are also one of the first places where customers go to see what experiences other have had with a brand or service. As companies also invest in building a social media presence more and more, it is easy to find information about brands on social media.

\section{Information contribution}

It has never been easier to share your opinion or voice with the public. Uploading videos and photographs can be done with the click of a button. It is also possible to comment on bad service or frustration with a companies' processes or employees in an instant. Sharing an experience you had with a particular product or service be it good or bad. With RSS you are also able to subscribe to receive new information that is added online as soon as it is uploaded.

\section{Importance of social media use}

Whiting and Williams (2013) looked at social media by considering the uses and gratifications theory. This theory is based on the foundation that individuals will look for media that fulfil their needs and that it will lead to gratification.
As with the consumption and use of other media channels, the importance of knowing how students use social media lies in segmentation and targeting of the market. If we are aware of how social media is used it is easier to tailor a marketing offering for the specific target market. The tailoring of a marketing strategy is something that universities need to consider as today's students adjust to the latest communication media rapidly as technology is so integrated into their lives (Voss and Kumar, 2013).

In Generation Y's lifetime (18-30 years old) they have not spent a day without computers. They spend their time daily on contributing and sharing information, searching for information online and consuming content; be it for work or for play (Bolton, Parasuraman, Hoefnagels, Migchels, Kabadayi, Gruber, Loureiro and Solnet, 2013). Several research studies have been conducted on how Generation Y uses social media (Barcelos and Rossi, 2014; Constantinides and Stagno, 2011; Lenhart, Purcell, Smith and Zickuhr, 2010). Younger generations use social media actively and frequently for socializing mostly via cell phones (Barcelos and Rossi, 2014). Where older generations used to socialize in face to face, for younger generations this space has moved online. The way in which older consumers use social media is still unclear.

\section{Methodology}

The main aim of this study is to establish how South African ODL students use social media. More specifically, the following objectives are set:

- To determine how much time students spend on social media.

- To determine the social media usage of ODL students.

- To determine if there is a difference in social media usage of different age groups of ODL students.

4.1. Sampling. The sampling frame for this study was the database of first-year students of the College of Economic and Management Sciences (CEMS). From this database of email addresses a sample of 10000 was drawn due to the fact that the response rate of online surveys is very low. The aim of this research study was to achieve a minimum response rate of 150 respondents.

The sample for this study was drawn from the target population using probability sampling, in the form of convenience sampling. The database was loaded into SAS Jump and a random number generator was run to select a simple random sample of students.

4.2. Data collection. Survey research was used as it was possible to collect the relevant data by asking specific questions regarding behavior when 
information was collected. This method of data collection has also been used in previous studies of this nature (Simões and Soares, 2010; Brown et al., 2009; Bonnema and van der Waldt, 2008; Wiese, 2008; Briggs and Wilson, 2007; Veloutsou et al., 2005; Hoyt and Brown, 2003; Moogan and Baron, 2003; Moogan et al., 2003).

A 16-item, 5-point Likert scale was used to measure social media usage. The items consisted of a number of activities that social media can be used for. The scale points were labelled from 1 (Never) to 5 (Always). A higher score indicates that the student engaged in this activity a lot on social media, whereas a lower score indicates that they did not engage in the activity often. The original scale used by Constantinides and Stagno (2011) contained three different elements that represented information-adding activities, information-seeking activities and entertainment activities. Respondents were also asked to indicate how many times per day they accessed social media and how many hours a day they spend on social media.

4.3. Reliability and validity assessment. The scale was employed to determine what activities respondents use social media for the most in the three categories as can be seen in the table below. In the original study Cronbach's alpha was reported for all three factors. Cronbach's alpha for this study for all the factors indicates good scale reliability as they are larger than 0.7, as can be seen in Table 2 below.
Table 2. Reliability assessment results for social media usage scale

\begin{tabular}{|c|c|c|}
\hline Dimension & Items & $\begin{array}{c}\text { Cronbach's } \\
\text { Alpha }\end{array}$ \\
\hline \multirow{5}{*}{ Entertainment } & Stay in touch & \multirow{5}{*}{0.859} \\
\hline & View: Pictures and videos & \\
\hline & Make appointments & \\
\hline & Share: Pictures and videos & \\
\hline & Search: New contacts & \\
\hline \multirow{6}{*}{$\begin{array}{l}\text { Information } \\
\text { adding }\end{array}$} & Share: Opinions and forums & \multirow{6}{*}{0.909} \\
\hline & Review: Purchased products & \\
\hline & Share: Experiences on blogs & \\
\hline & Vote in polls & \\
\hline & Share information: Sport/hobby & \\
\hline & Share information: Universities & \\
\hline \multirow{4}{*}{$\begin{array}{l}\text { Information } \\
\text { seeking }\end{array}$} & Search for information about studies & \multirow{4}{*}{0.924} \\
\hline & Search for information about university & \\
\hline & Search for information about school & \\
\hline & Read product reviews & \\
\hline
\end{tabular}

\section{Results}

5.1. Profile of participants / Respondent profile. Age and gender variables were used to construct a profile of first-year students in CEMS at Unisa that responded to the survey. The gender distribution of the respondents indicated that that $59.0 \%(\mathrm{n}=92)$ of the respondents were female and $41.0 \%(\mathrm{n}=64)$ were male. The age distribution of respondents can be seen in Figure 1 below. As can be seen the majority of the respondents are 30 years and younger $(69.8 \%)$.

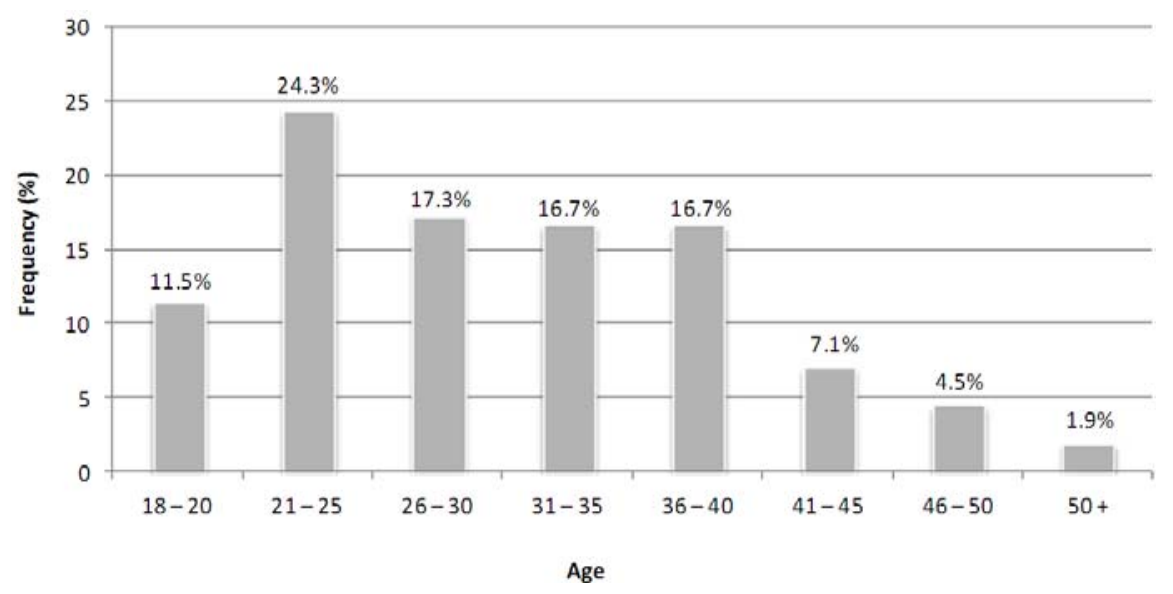

Fig. 1. Respondents' age distribution $(n=156)$

5.2. Results. With regard to how many times a day respondents accessed social media, the majority of the respondents accessed social media between 1 and 3 times per day $(47.1 \% ; \mathrm{n}=72)$. There were 35 respondents (22.9\%) who accessed social media 4-6 times a day and 27 respondents (17.6\%) did so more than 10 times a day. Only 7.7\% ( $\mathrm{n}=12)$ of respondents indicated that they did not access social media and 3 respondents did not answer the question. The data suggests that $90.3 \%$ of respondents accessed social media on a daily basis. There were 3 respondents that did not answer the question.

Respondents were also asked how many hours per day they spent on social media. This ranged from no time to more than 10 hours per day. The data suggest that the majority of the respondents spent between 1 and 3 hours per day on social media, with 107 respondents $(69.5 \%)$ selecting this option. 16 respondents (11.0\%) spent 4-6 hours a day on social media. There were 2 respondents that did not 
answer the question. It is safe to assume that ODL students spend 1-3 hours per day on social media.

Overall, respondents indicated that they made more use of entertainment activities on social media, with a mean of $3.02(S D=0.94)$ than any other activity. Information-seeking activities were in second place $(M=2.90 ; S D=1.28)$, with information-adding activities in last place $(M=2.36 ; S D=1.06)$. The most popular activities under each factor were to stay in touch with contacts $(M=3.38 ; S D=1.11)$, to view pictures and videos $(M=3.38 ; S D=1.12)$, to search for information about studies $(M=3.12$; $S D=1.41)$ and to share opinions and views on forums $(M=2.76 ; S D=1.34)$.

The least popular activities under each category were to make appointments with contacts $(M=2.54$; $S D=1.26)$, to search for information about school $(M=2.66 ; S D=1.44)$ and to subscribe to RSS feeds $(M=1.81 ; S D=1.55)$.

Table 2. Social media usage - descriptive statistics

$$
(n=156)
$$

\begin{tabular}{|l|c|c|}
\hline Items & $M$ & $S D$ \\
\hline Total social media usage & 2.70 & 0.95 \\
\hline & & \\
\hline Total entertainment & $\mathbf{3 . 0 2}$ & $\mathbf{0 . 9 4}$ \\
\hline Stay in touch & 3.38 & 1.11 \\
\hline View: Pictures and videos & 3.38 & 1.12 \\
\hline Make appointments & 2.54 & 1.26 \\
\hline Share: Pictures and videos & 3.21 & 1.20 \\
\hline Search: new contacts & 2.58 & 1.18 \\
\hline & & \\
\hline Total information seeking & $\mathbf{2 . 9 0}$ & $\mathbf{1 . 2 8}$ \\
\hline Search: Info about study & 3.12 & 1.41 \\
\hline Search: Info about university & 2.99 & 1.43 \\
\hline Search: Info about school & 2.66 & 1.44 \\
\hline Read: Product reviews & 2.81 & 1.38 \\
\hline & & \\
\hline Total information adding & $\mathbf{2 . 3 6}$ & $\mathbf{1 . 0 6}$ \\
\hline Share: Opinions on forums & 2.76 & 1.34 \\
\hline
\end{tabular}

\begin{tabular}{|l|c|c|}
\hline Review: Purchased products & 2.58 & 1.36 \\
\hline Share: Experiences on blogs & 2.09 & 1.26 \\
\hline Subscribe: RSS & 1.81 & 1.15 \\
\hline Vote & 2.23 & 1.30 \\
\hline Share information: sport/hobby & 2.46 & 1.32 \\
\hline Share information: Universities & 2.54 & 1.44 \\
\hline
\end{tabular}

Notes: Scale values range from 1 (Never use) to 5 (Always use); the higher a mean score, the more the respondent used this activity on social media. $n=$ number of respondents, $M=$ mean, $S D=$ standard deviation.

The data suggest that social media play an entertainment role in most ODL students' lives by helping them stay in touch with contacts and allowing them to view pictures and videos online. There is also a slight inclination towards social media playing an information-seeking role.

\section{Social media usage in different age categories}

Table 3 below illustrates the differences in social media usage between respondents of 31 years and older and respondents of 18-30 years old. Respondents of 18-30 years of age (Generation Y) mostly used social media for entertainment purposes. The reported mean score is 3.01 ( $S D=$ 0.88 ). The mean is slightly dispersed, which could indicate that respondents had slightly different views on their usage of social media. The average view was that 18-30 years old respondents made use of social media for entertainment purposes. Respondents aged 31 years and older used social media as an information-seeking platform. The reported mean score is $3.10(S D=1.33)$. The mean is widely dispersed, which could indicate that respondents had very different views on their usage of social media. The average view was that respondents of 31 years and older mostly made use of social media for information-seeking activities. The least popular social media usage in both groups was information-adding activities $(M=2.31$; $S D=1.092$ and $M=2.42 ; S D=1.019$ ).

Table 3. Differences in social media usage between age groups $(n=155)$

\begin{tabular}{|l|c|c|c|c|c|c|c|}
\hline & \multirow{2}{*}{$n$} & \multicolumn{2}{|c|}{ Total entertainment } & \multicolumn{2}{|c|}{ Total information seeking } & \multicolumn{2}{c|}{ Total information adding } \\
\cline { 3 - 8 } & & $m$ & $S D$ & $m$ & $S D$ & $m$ & $S D$ \\
\hline 18-30 years & 82 & 3.01 & 0.876 & 2.72 & 1.214 & 2.31 & 1.092 \\
\hline 31 years and older & 73 & 3.04 & 1.009 & 3.10 & 1.331 & 2.42 & 1.019 \\
\hline Total & 155 & 3.02 & 0.938 & 2.90 & 1.280 & 2.36 & 1.056 \\
\hline
\end{tabular}

Taking the above discussion into consideration, ODL students of 18-30 years appear to be mainly engaging in entertainment activities on social media. They enjoy activities such as viewing and sharing pictures and videos, looking for new contacts and staying in touch with contacts. On the other hand, 31 years and older ODL students enjoy informationseeking activities on social media slightly more than entertainment. They like to search for different types of information on social media and even read product reviews. From this it is clear that in order to capture the attention of these two different age groups on social media, universities will need to make use of different types of strategies.

Although no formal hypothesis was stated in the study, the same method was used to investigate the difference in social media usage between the two 
groups. For the purpose of statistical analysis the following hypothesis was formulated:

$H_{l(n u l l)}$ : There is no difference in the usage of social media across different age groups.

$H_{\text {l(alt) }}$ : ODL students from different age groups differ regarding the way in which they use social media.

As this is a hypothesis that is comparing two groups on the same interval variable, the parametric twosample $t$-test was identified as a possible hypothesis test. There are, however, three assumptions that need to be true for the parametric test to be done. If the data violate these assumptions, it will not be able to test the hypothesis at a parametric level and it will need to be tested at a non-parametric level, which will be the Mann-Whitney U test (also known as the Wilcoxon rank sum test). The level of significance against which the results of the hypothesis were tested, is $\alpha=0.05$.

The descriptive statistics for different age groups were developed and can be seen in Table 4 below.

Table 4. Descriptive statistics of the perceived credibility of social media variable on different age groups

\begin{tabular}{|l|c|c|c|c|}
\hline \multicolumn{1}{|c|}{ Age group } & $n$ & $M$ & $S D$ & Median \\
\hline Generation $Y$ students & 82 & 2.63 & 0.103 & 2.47 \\
\hline Older students & 73 & 2.78 & 0.113 & 2.69 \\
\hline
\end{tabular}

From the table, the descriptive statistics clearly suggest that there is not a significant difference between social media usage of ODL Generation Y students $(M=2.63 ; S D=0.103)$ and older ODL students $(M=2.78 ; S D=0.113)$. The standard deviation indicates that there was no consensus in these age groups regarding social media usage.
In order to see if the parametric test could be used, a test needed to be done to test the assumption of normality. The statistical tests for assumption of normality are explained by looking at the results of the Kolmogorov-Smirnov (KS) and Shapiro-Wilk tests for normality. Since each age group had more than 50 respondents, the KS test was used to interpret the results and can be seen in the table below.

Table 5. Kolmogorov-Smirnov test for normality

\begin{tabular}{|l|c|c|c|}
\hline \multirow{2}{*}{ Age group } & \multicolumn{3}{c|}{ Kolmogorov-Smirnov } \\
\cline { 2 - 4 } & Statistic & $\mathrm{df}$ & $\mathrm{Sig}$ \\
\hline Generation Y students & 0.086 & 82 & 0.200 \\
\hline Older students & 0.069 & 73 & 0.200 \\
\hline
\end{tabular}

The $p$-value of the KS test is significant; if the $p$-value is smaller than 0.05 , it means that the test variable has a non-normal distribution in that group. The $p$-value for Generation Y ODL students is 0.200 and for older ODL students it is 0.200 . Both $p$-values are greater than 0.05 , which means that the groups have a normal distribution. This is supported by the graphical tests for the assumption of normality, which clearly show that the social media usage variable has a normal distribution in both of the two age sub-groups. From this it is concluded that the independent sample $t$-test (parametric test) was appropriate as assumption of normality was normal.

The relevant parametric test was thus used to test the hypothesis; in this case the assumption of normality had already been dealt with and equal variances were then tested using Levene's test for equality of variances. Levene's test tests the null hypothesis that the test variable (total social media usage) has equal variances in the two groups being compared. If the $p$-value of Levene's test for equality was less than 0.05 , the assumption of equal variances would be rejected.

Table 6. Parametric hypothesis test

\begin{tabular}{|l|c|c|c|c|c|c|c|c|}
\hline & \multicolumn{2}{|c|}{$\begin{array}{c}\text { Levene's test for } \\
\text { equality of variances }\end{array}$} & \multicolumn{3}{|c|}{ t-test for equality of means } \\
\cline { 2 - 9 } & $\mathrm{F}$ & $\mathrm{Sig}$ & $\mathrm{t}$ & $\mathrm{df}$ & $\begin{array}{c}\text { Sig. } \\
(2 \text {-tailed })\end{array}$ & Std error difference & \multicolumn{2}{|c|}{$95 \%$ confidence interval of the difference } \\
\cline { 2 - 9 } & & & & & & & Lower & Upper \\
\hline Equal variances assumed & 0.166 & 0.684 & -0.983 & 153.000 & 0.327 & 0.15236 & -0.45072 & 0.15127 \\
\hline Equal variances not assumed & & & -0.981 & 149.540 & 0.328 & 0.15267 & -0.45140 & 0.15195 \\
\hline
\end{tabular}

The $p$-value of Levene's test for equality of variances is 0.684 . Since this value is greater than 0.05 , the null hypothesis of equal variance cannot be rejected. The conclusion therefore has to be that the variance of the total social media usage variable in the Generation Y ODL students is the same as that in the older ODL students. Consequently, the results of the t-test which appear in the first row of the independent samples test output table just below the column headings have to be considered. The $p$-value of the t-test (equal variances assumed) is 0.327 .
This, however, is a two-tailed $p$-value and a onetailed hypothesis was formulated. As a result, the one-tailed $p$-value has to be calculated. Thus the one-tailed $p$-value is $1-(0.327 / 2)=0.8365$.

Since this is not less than 0.05 , the null hypothesis of equal group means cannot be rejected. It is thus concluded that in this study, Generation Y ODL students and older ODL students do not differ significantly in their social media usage as measured by the social media usage scale. 


\section{Conclusion}

The first objective was to determine how much time ODL students spend on social media. Respondents were asked to indicate how many times per day they accessed social media. The majority of ODL students $(90.3 \% ; n=134)$ accessed social media more than once a day. The most accessed it 1-3 times a day $(47.1 \% ; n=72)$. Respondents were also asked to indicate how many hours a day they spent on social media. The results indicate that $69.5 \%$ of the ODL students $(n=107)$ spent $1-3$ hours on social media and $15.5 \%$ spent more than 4 hours a day on social media. Taking the above into consideration, universities should investigate how they can capitalize on their ODL students spending such a large amount of time on social media and how they can communicate with their target market effectively using social media. From this study it is clear that ODL students are present online and using social media on their cellphones. Universities should make sure that the content they put on social media is optimized for use on a cellphone.

The second objective of this study was to determine how ODL students use social media and the third objective if ODL students in different age groups differ in their use of social media. Table 2 earlier on, suggests that respondents overall used social media for entertainment purposes. Entertainment had a reported mean of $3.02(S D=0.94)$. Information seeking was the second most used activity $(M=2.90 ; S D=1.28)$, followed by information adding ( $M=2.36 ; S D=1.06)$.

The inferential statistics indicate that the sub-groups (Generation Y ODL students and older ODL students) did not differ significantly in their social media usage as measured by the social media usage scale. This can be seen in Table 3, 4 and 5 earlier on. There is, however, a slight difference between the means in the activities that they engaged in on social media. In Table 3 the difference between social media usage of Generation Y respondents and older students was reported. From the findings it was interesting to note that Generation Y respondents mostly used social media for entertainment activities, whereas older respondents used it for information-seeking activities.

Respondents of different age categories indicated that they used social media differently, so universities can use this information when adding content to their social media platforms. They can create and add different types of content in each category aimed at different users. For example, a fun video that promotes the university can be targeted at younger students, whereas older students will mostly be interested in factual information in the form of a link to information on different social media platforms like a LinkedIn Group.

Limitations include that the sample was only drawn from Unisa first-year students, and thus it is not a representative view of all first-year students and results cannot be generalized. The study may yield different results in a residential university setting or in a different context. Correspondence students need to be on the internet for tuition. The social media usage and time spent on social media do not appear to differ much between the different age groups. Further research could investigate if this is the case for a different sample of these groups in another setting.

\section{References}

1. Agichtein, E., Castillo, C., Donato, D., Gionis, A. and Mishne, G. (2008). Finding High-Quality Content in Social Media. Paper presented at the first ACM International Conference on Web Search and Data Mining, California, 11-12 February, pp. 183-193.

2. Alexa. (2015). Top Sites in South Africa. Available at: http://www.alexa.com/topsites/countries/ZA.

3. Anon. (2015). Statista: The Statistics Portal. Available at: http://www.statista.com/.

4. Barker, M., Barker, D., Bormann, N. and Neher, K. (2013). Social media marketing: A strategic approach. SouthWestern Cengage Learning.

5. Barnes, N.D. and Barnes, F.R. (2009). Equipping your organization for the social networking game, Information Management Journal, 43 (6), pp. 28-47.

6. Bolotaeva, V. and Cata, T. (2011). Marketing opportunities with social networks, Journal of Internet Social Networking and Virtual Communities, 10.

7. Bolton, R.N., Parasuraman, A., Hoefnagels, A., Migchels, N., Kabadayi, S., Gruber, T., Loureiro, Y.K. and Solnet, D. (2013). Understanding Generation Y and their use of social media: a review and research agenda, Journal of Service Management, 24 (3), pp. 245-267.

8. Constantinides, E. and Fountain, S.J. (2007). Web 2.0: Conceptual foundations and marketing issues, Journal of Direct, Data and Digital Marketing Practices, 9 (2), pp. 231-244.

9. Constantinides, E. and Stagno, M.C.Z. (2011). Potential of the social media as instruments of higher education marketing: a Segmentation study, Journal of Marketing for Higher Education, 21 (1), pp. 7-24.

10. Cooper, D.R. and Schindler, P.S. (2006). Business research methods. $9^{\text {th }}$ edition. New York: McGraw-Hill.

11. Daugherty, T., Eastin, M.S. and Bright, L. (2010). Exploring consumer motivations for creating user-generated content, Journal of Interactive Advertising, 8 (2), pp. 16-25.

12. de Valck, K., van Bruggen, G.H. and Wierenga, B. (2009). Virtual communities: A marketing perspective, Decision Support Systems, 47, pp. 185-203. 
13. Dlodlo, N. and Dhurup, P.M. (2013). Examining social media dimensions among a cohort of Generation Y consumers in South Africa, Mediterranean Journal of Social Sciences, 4 (14), pp. 329-338.

14. du Plessis, F., Bothma, N., Jordaan, Y. and van Heerden, N. (2005). Integrated marketing communication. $2^{\text {nd }}$ edition. Claremont: New Africa Books.

15. du Plessis, T.C. (2010). Theoretical guidelines for social media marketing communication, Communicare, 29 (1), pp. 1-20.

16. Facebook. (2015). Press Room: Statistics. Available at: http://www.facebook.com/press/info.php?statistics.

17. GetSmarter. (2012). Social media course: Module 1 course notes. Cape Town: Management Sciences, University of Cape Town.

18. Gillin, P. (2007). The new influencers: A marketer's guide to the new social media. California: Quil Driver Books.

19. Graham, J.M., Faix, A. and Hartman, L. (2009). Crashing the Facebook party: One library's experiences in the students' domain, Library Review, 58 (3), pp. 228-236.

20. Heinonen, K. (2011). Consumer activitiy in social media: Managerial approaches to consumers' social media behavior, Journal of Consumer Behavior, 10, pp. 356-364.

21. Kronberger, M. (2009a). Research reveals how young people are consuming social media. Available at: http://www.studentmarketing.co.za/portfolio/first-time-research-reveals-how-young-people-are-consuming-socialmedia-in-south-africa/.

22. Kronberger, M. (2009b). SA Students are Watching Less TV and Spending More Time Online. Available at: http://www.studentmarketing.co.za/sa-students-are-watching-less-tv-and-spending-more-time-online/.

23. Lenhart, A., Purcell, K., Smith, A. and Zickuhr, K. (2010). Social media \& mobile internet use among teens and young adults. Available at: www.pewresearch.org/millennials.

24. Makrez, H.M. (2015). Am I invited? Social media and alumni relations, Higher education administration with social media, 2, pp. 229-248.

25. Malhotra, N.K. (2010). Marketing research: An applied orientation. $6^{\text {th }}$ edition. New Jersey: Pearson.

26. Mangold, W.G. and Faulds, D.J. (2009). Social media: The new hybrid element of the promotion mix, Business Horizons, 52, pp. 357-365.

27. Packer, R. (2011). Social media marketing: The art of conversational sales. Available at: http://www.wsimarketbuilders.com/socialmediamarketingwhitepaper. pdf.

28. Patricios, O. (2009). Social media will reinvent brands. Available at: http://reference.sabinet.co.za/webx/access/electronic_journals/mfsa1/mfsa1_apr_2009_a16.pdf.

29. Pew Research Centre A. (2015). Social media use by age group over time. Available at: http://www.pewinternet.org/data-trend/social-media/social-media-use-by-age-group/.

30. Pew Research Centre B. (2015). Social media update 2013. Available at: http://www.pewinternet.org/2013/12/30/social-media-update-2013/.

31. Barcelos, R.H. and Rossi, C.A.V. (2014). Paradoxes and strategies of social media consumption among adolescents, Young Consumers, 15 (4), pp. 275-295.

32. Safko, L. (2010). The social media bible: Tactics, tools and strategies for business success. Hoboken, Hoboken: John Wiley \& Sons.

33. Safko, L. and Brake, D.K. (2009). The social media bible: Tactics, tools and strategies for business success. Hoboken, N.J.: John Wiley \& Sons.

34. Schultz, R.J., Schwepker, C.H. and Good, D.J. (2012). Social media usage: an investigation of B2B salespeople, American Journal of Business, 27 (2), pp. 174-194.

35. Scott, D.M. (2007). The new rules of marketing \& PR. New Jersey: Wiley.

36. Shezi, L. (2015). What do SA's 24.9 million internet users spend most of their time doing online? Available at: http://www.htxt.co.za/2015/01/21/what-do-sas-24-9-mil-internet-users-spend-most-of-their-time-doing-online/.

37. Solis, B. (2015). The Conversation Prism Version 4.0. Available at: https://conversationprism.com/.

38. Statista A. (2014). Global consumer interactions with retail brands on social media as of September 2014 by age. Available at: http://www.statista.com/statistics/411895/consumer-social-media-interactions-with-brands-age/.

39. Thackeray, R., Neiger, B.L., Hanson, C.L. and McKenzie, J.F. (2008). Enhancing promotional strategies within social marketing programs: Use of Web 2.0 social media, Health Promotions Practice, 9 (4), pp. 338-343.

40. Voss, K.A. and Kumar, A. (2013). The value of social media: are universities successfully engaging their audience, Journal of Applied Research in Higher Education, 5 (2), pp. 156-172.

41. Weinberg, B.D. and Pehlivan, E. (2011). Social spending: Managing the social media mix, Business Horizons, 54, pp. 275-282.

42. Wertime, K. and Fenwick, I. (2008). Digimarketing: The essential guide to new media \& digital marketing. Singapore: Wiley \& Sons.

43. Whiting, A. and Williams, D. (2013). Why people use social media: a uses and gratifications approach, Qualitative Market Research: An International Journal, 16 (4), pp. 362-369.

44. Wiid, J. and Diggines, C. (2013). Marketing research. $2^{\text {nd }}$ edition. Cape Town: Juta.

45. Xiang, Z. and Gretzel, U. (2010). Role of social media in online travel information search, Tourism Management, 31, pp. 179-188.

46. Young, A. (2009). Online social networking: An Australian perspective, International Journal of Emerging Technologies and Society, 7 (1), pp. 39-57.

47. Zarrella, D. (2009). The social media marketing book. California: O’Reilly Media. 